\title{
Two Cases of Recurrent Nasal Polyps in Siblings-Woakes' Syndrome
}

\author{
Chang Bae Lee, Nam Yoon Jung, Young Jin Loh, and Woo Yong Bae \\ Department of Otolaryngology-Head and Neck Surgery, Dong-A University College of Medicine, Busan, Korea
}

\section{형제에서 발견된 재발성 비용종 2예-Woakes' 증후군}

이창배 · 정남윤 · 노영진 · 배우용

동아대학교 의과대학 이비인후-두경부외과학교실

\author{
Received December 25, 2017 \\ Revised April 4, 2018 \\ Accepted April 16, 2018 \\ Address for correspondence \\ Woo Yong Bae, MD, PhD \\ Department of Otolaryngology- \\ Head and Neck Surgery, \\ Dong-A University \\ College of Medicine, \\ 26 Daesingongwon-ro, Seo-gu, \\ Busan 49201, Korea \\ Tel $+82-51-240-5423$ \\ Fax $+82-51-253-0712$ \\ E-mail doncamel@dau.ac.kr
}

\begin{abstract}
Woakes' syndrome is a group of disease which include recurrent nasal polyps resulting in the broadening of the nasal pyramid, the onset of hypoplasia of frontal sinus and bronchiectasis, as well as the production of mucous discharge. Children and young adults are mostly susceptible to Woakes' syndrome due to the plasticity of the bone. Even though the exact etiology is unknown, genetic factor is thought to be influential because it is often diagnosed in siblings. Otolaryngologically, the mainstream method of removing nasal polyp by endoscopic sinus surgery as well as topical or systemic treatment can be helpful. We report two siblings who visited our clinic both complaining of nasal obstruction. The patients presented with recurrent nasal polyps and showed signs of bronchiectasis, which led to the diagnosis of Woakes' syndrome. These rare cases are presented here with a review of related literature.
\end{abstract}

Korean J Otorhinolaryngol-Head Neck Surg 2019;62(4):250-4

Key Words Bronchiectasis · Endoscopic sinus surgery · Nasal polyp · Woakes' syndrome.

\section{서 론}

Woakes' 증후군은 외비의 확장을 유발하는 재발성 비용 종, 전두동의 발달 부전, 비용종, 점액성 콧물을 증상으로 하 는 증후군이다. 유병률은 낮은 편이나 재발하는 비용종과 전 두동의 발달 부전, 코의 변형 등과 함께 기관지 확장증도 동 반될 수 있다. ${ }^{1)}$ Woakes' 증후군의 정확한 분자 생물학적 기 전은 알려져 있지 않으나 형제에서 생기는 경우도 보고되고 있어 유전 질환으로 분류되고 있다. ${ }^{2}$

이 질환의 치료로는 항생제, 스테로이드 약물치료와 비용 종에 대한 제거술과 함께 염증 제거를 위한 내시경 부비동 수 술이 시행되고 있으나 재발 소견이 많아 장기적인 치료 계획

This is an Open Access article distributed under the terms of the Creative Commons Attribution Non-Commercial License (https://creativecommons.org/licenses/by-nc/4.0) which permits unrestricted non-commercial use, distribution, and reproduction in any medium, provided the original work is properly cited.
수립이 필요하다.3) 저자들은 수년간 재발하는 비용종으로 내 원한 형제에서 진단된 Woakes' 증후군 2예를 치험 하였기에 문헌고찰과 함께 보고하고자 한다.

\section{증 계}

\section{증 례 1}

19세 남자 환자로 5 세경 때부터 비폐색 및 비강 내 비용종 소견으로 타 병원에서 4회에 걸쳐서 비용종 제거술 시행하였 으며, 13 세 경에 다시 재발한 양측 비폐색 소견으로 본원 내 원하였다. 비폐색 외 밤에 심해지는 기침을 호소하였고 그 외 다른 특이 증상은 없었다. 전산화단층촬영에서 양측 전두동 과 상악동 및 개구비도단위(ostiomeatal unit)에서 연조직 음 영이 관찰되었다(Fig. $1 \mathrm{~B})$. 전비경 검사에서 양측에 비용종 (Fig. 1A)과 점액성 비루가 관찰되었다. 알레르기 검사상에 
총 $\operatorname{IgE}$ 42.5(정상치: 0 200)였고 CAP 상에서도 음성 결과가 나왔다. 기관지 유발시험에서도 결과가 음성으로 나왔다. 부 비동 내시경 수술 및 비용종 제거술을 시행하였고 이후 지속 적으로 일반적인 부비동 수술 후 치료와 같은 방법으로 치료 받았으나, 비용종 재발 소견을 보여 14세, 15세에 재수술을 시행하였다. 이후 19 세에 비용종에 의한 비폐색이 심해져 수 술을 계획하였으며 전산화단층촬영에서는 다시 연조직 음영
이 관찰되었다. 전비경 검사에서는 양측 비강에 비용종 재발 소견 관찰되었다. 검사 도중 이전에는 관찰되지 않은 폐병변 이 관찰되어 호흡기 내과에 의뢰하였고, 흥부 전산화단층촬 영상에서는 기관지 확장증으로 진단되었다(Fig. 1D).

환자는 이후 부비동 내시경 수술을 시행하였으며, 수술 중 의 병리조직검사 결과는 만성 호산구성 침윤이 없는 비용종 소견이 도출되었다(Fig. 1E). 이후 현재까지는 증상 및 비용
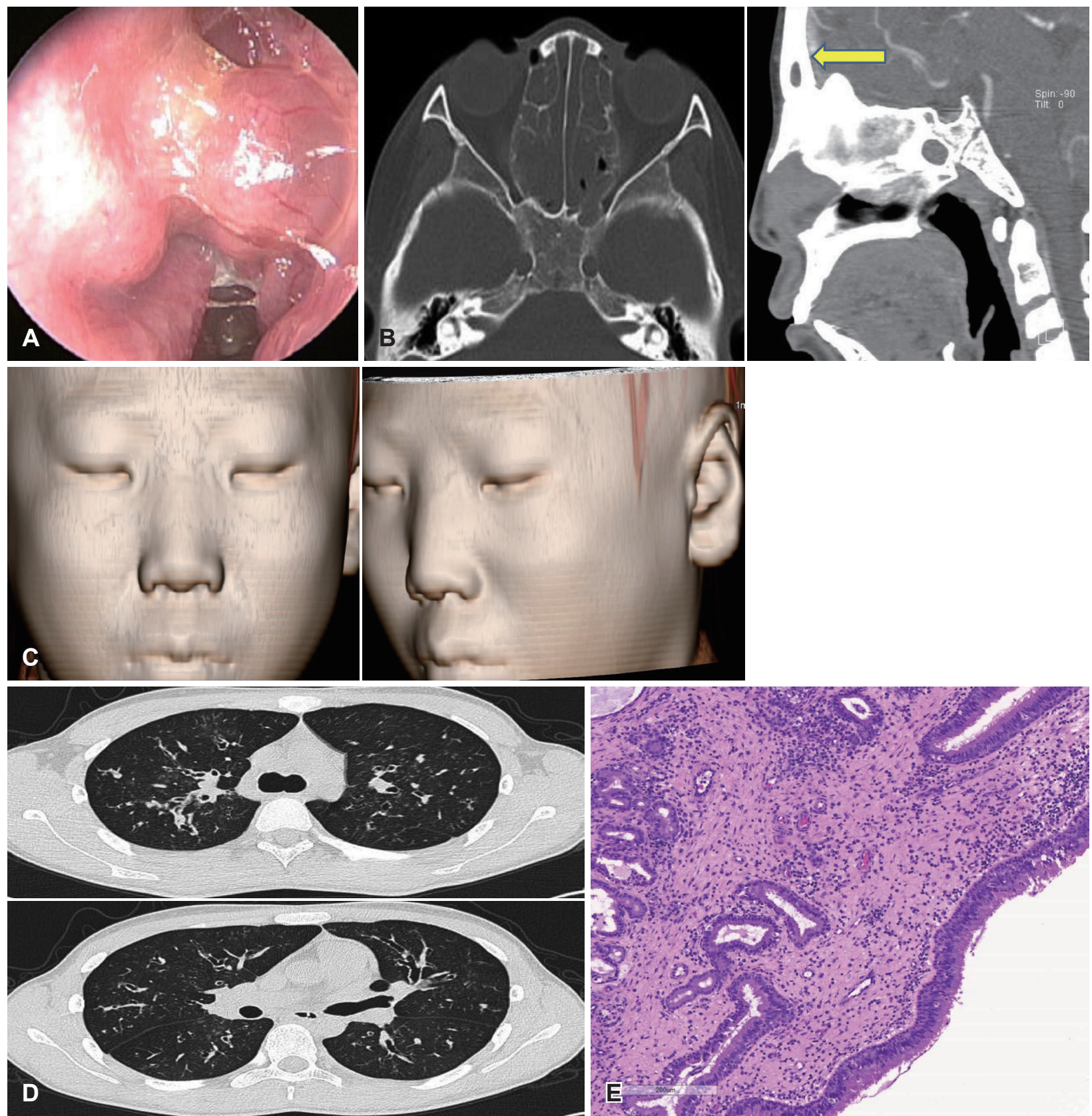

Fig. 1. In case 1. Endoscopic finding shows nasal polyp and thick viscous discharge of the left nasal cavity (A). CT scan showing nasal polyp in both nasal cavity and showing the hypoplasia of the frontal sinus (arrow) (B). Three dimensional reconstruction of CT showing normal nasal shape (C). A chest CT showing dilated bronchioles (D). A pathologic finding of a nasal polyp showed loose myxoid stroma coverd by respiratory muscosa and chronic inflammation with lack of eosinophil infiltration (hematoxylin and eosin stain, $\times 200)(E)$. CT: computed tomography. 
종 재발 소견 없이 정기적인 외래 관찰 중이다. 기관지 확장 증은 수술 3 개월 후, 폐 방사선 사진 촬영에 변화가 없어서 주기적으로 호흡기 내과 외래에서 관찰하기로 계획하였다.

\section{증 례 2}

14세 남자 환자로 수년 전부터 시작된 양측 비폐색 소견으
로 타 병원 진료에서 양측 만성 부비동염 및 비용종 소견으 로 8세에 본원 내원한 환자로 본원에서 3차례에 걸쳐 부비동 내시경 수술 및 비용종 제거술을 시행한 환자이다. 이전 수 술 시행 전 촬영한 부비동 전산화단층촬영에서는 전두동의 저형성 소견 및 상악동과 개구비도 단위에서의 연조직 음영 이 관찰되었다(Fig. 2B). 이후 외래 통해서 항생제 및 항히스
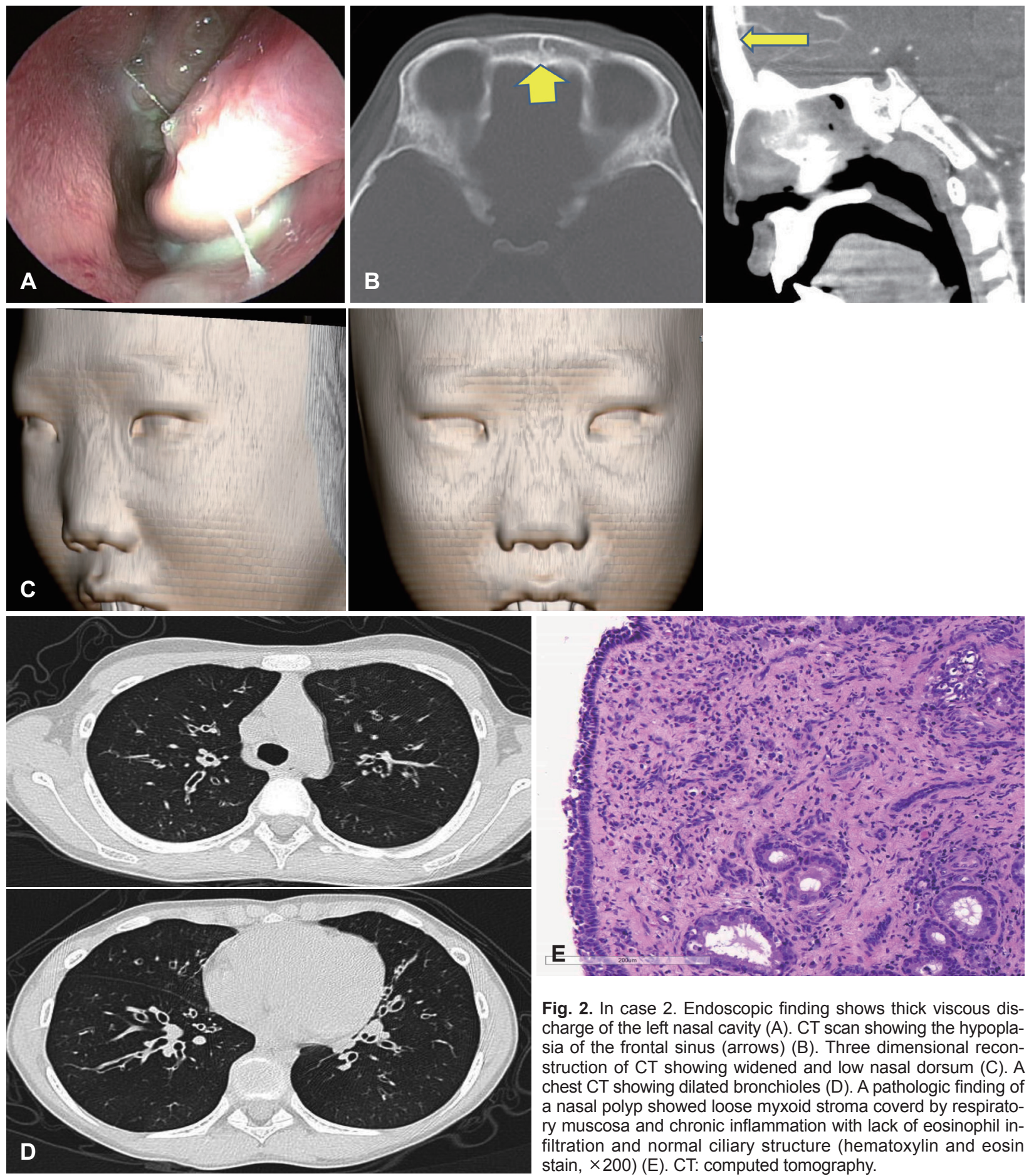

Fig. 2. In case 2. Endoscopic finding shows thick viscous discharge of the left nasal cavity (A). CT scan showing the hypoplasia of the frontal sinus (arrows) (B). Three dimensional reconstruction of CT showing widened and low nasal dorsum (C). A chest CT showing dilated bronchioles (D). A pathologic finding of a nasal polyp showed loose myxoid stroma coverd by respiratory muscosa and chronic inflammation with lack of eosinophil infiltration and normal ciliary structure (hematoxylin and eosin stain, $\times 200)(E)$. CT: computed tomography. 
타민제 치료 및 경과관찰 하였으나, 13세경 다시 증상 악화되 었다. 전비경 검사에서 양측 비용종 및 점액성 비루가 관찰되 었고(Fig. 2A), 외비의 확장 소견도 다소 관찰되었다(Fig. 2C). 전산화단층촬영에서도 부비동염의 재발 소견과 비용종 소견 을 보여서 수술을 계획하였다. 수술 전 검사상 흥부 방사선 사 진에서 이전에 관찰되지 않았던 기관지 확장증 소견 의심되 어 호흡기내과에 의뢰되었고, 흥부 방사선단층촬영에서 기관 지 확장증 확증되었고(Fig. 2D), 폐 기능 검사상 forced expiratory volume(FEV1)은 68\%, forced vital capacity(FVC)는 $78 \%$ 로 정상 소견보여 특별한 치료 없이 관찰하기로 하였다. 이후 환자는 양측 부비동 내시경 수술을 시행하였고 수술 중 시행한 병리검사 결과, 비용종 소견이 있었으나 호산구의 침윤 은 관찰되지 않았다(Fig. 2E). 환자는 현재까지 증상 호전 및 재발 소견 없이 이후 본원 외래 통해서 정기적인 관찰 중이다. 또한 수술 3개월 후 촬영한 흥부 방사선 소견에서 변화 소견이 관찰되지 않아 정기적으로 관찰 중이다.

\section{고 찰}

Woakes' 증후군은 흔하지 않은 질환으로 유년 시절에 발생 하는 재발성 비용종, 점성이 강한 분비물, 전두동의 발달 저 하, 기관지 확장증의 4 가지 특징을 보이는 질환 군을 말한다. 이는 매우 드문 질환으로 국내에서는 아직 보고된 바가 없으 며 외국에서는 1885년 Edward Woakes'에 의해 보고된 이 후 드물게 보고되고 있다.,3)

임상증상으로는 코막힘, 콧물, 코피, 후각저하, 두통, 심한 경우에는 시신경 압박으로 인한 진행성의 시각저하 등이 발 생할 수 있으며, 신체 진찰 시에는 비삼각의 확장, 양안 과다 격리증 등을 관찰 할 수 있다., ${ }^{14)}$ 비내시경상 비강을 채우는 비 용종을 볼 수 있으며 부비동 전산화단층촬영상에서는 전두 동의 발달 저하, 비강 및 부비동의 폐색, 골격의 변화 등을 볼 수 있다. ${ }^{2.5)}$ 형의 경우(증례 1) 전두동의 저형성증(hypoplasia) 소견이 관찰되지 않았으나 수차례에 걸쳐서 재발하는 비용종 소견과 기관지 확장증 소견은 Woakes' 증후군에 부합했다. 동생의 경우(증례 2) 외비의 확장 소견이 관찰되었고, 전산화 단층촬영에서 전두동 저형성 소견이 관찰되었으며, 14 세에는 이전에 보이지 않던 기관지 확장 소견도 관찰되어 Woakes' 증 후군의 특징적인 임상 양상을 보였다.

이 질환의 유병률은 낮은 편이지만 같은 형제에서 나타나 는 케이스도 보고되고 있어 유전질환일 확률이 높으나, 아직 정확한 기전은 밝혀지지 않았다. ${ }^{5)}$ 본 증례에서도 같은 형제에 서 나타나는 케이스로 유전질환의 가능성을 보여주고 있다.

감별 질환으로는 Cystic fibrosis, Kartagener's 증후군, 재
발하는 부비동염 등이 있을 수 있으나, Cystic fibrosis의 경우 Woakes' 증후군과 달리 위장관계나 내분비계 장애가 동반될 수 있으며 Kartagener's 증후군은 좌우바뀜증(Situs inversus) 이 동반되기도 한다. ${ }^{1)}$

치료는 내시경적 부비동 수술을 통한 비용종의 완전 제거 가 주를 이루며, 외비 변형이 심한 경우 비중격 성형술, 외비성 형술 등을 시행 할 수 있다. ${ }^{3,4}$ 본 증례에서는 부비동 내시경 수술을 몇 차례 시행하였으나, 외비성형술을 시행할 만큼의 외비의 변형은 관찰되지 않았다. 한 연구에서는 Woakes' 증 후군으로 코막힘, 콧물, 두통, 시각저하를 호소하던 환자에서 방사선 치료를 통해 비용종의 재발을 막은 사례도 있었으나 이에 대한 위험부담과 이득에 관해서는 연구가 더 필요한 실 정이다. ${ }^{6}$

약물치료 및 수술적 치료에도 불구하고 수차례 재발하는 치료 군은 면역결핍 질환과 유전적으로 특정한 유전자의 다 형태(polymorphism)을 감별하는 것도 도움이 될 것으로 보 인다.) 또한 약물과 수술적 치료에도 불구하고 재발하는 만 성 부비동염 환자군에서 배경적으로 면역 결핍이 있는 경우 도 있다. 가장 흔한 면역결핍 질환은 common variable immunodeficiency, specific antibody deficiency, Selective IgA deficiency 등이다. ${ }^{6,8)}$ 전체혈구계산(complete blood count differential count), 혈청 내 Streptococcus pneumoniae 등의 세균에 대한 혈청 항체와 immunoglobulin level을 측정하여 Woakes' 증후군에서도 같은 항체의 결핍이 있는지 관찰해보 는 것도 상기 진단의 감별진단에 도움이 될 것이다."

유전학적으로 $M M P 1$ gene의 $1 \mathrm{G} / 2 \mathrm{G}$ polymorphism 위치 가 어린 시기에 발병 하에 재발성이 있는 비용종을 동반하는 만성 부비동 증후군과 관계가 있다는 보고도 있어서 이를 확 인해 보는 것도 Woakes' 증후군이 유전적으로 상관성 있는 지 먼저 감별하는 데 도움이 될 것이다. ${ }^{79}$

뿐만 아니라 Woakes' 증후군은 약물이나 수술적 치료 후 에 재발하는 다른 만성 부비동염 질환 군에서도 근치적인 치 료를 위해서는 추가적인 유전학적 스크리닝 검사나 면역학적 검사 연구를 통해 각 질환의 분자생물학적 메커니즘을 명확 히 하고 난 뒤, 각 진단의 치료 방향에 대한 데이터를 확립하 는 연구가 필요할 것으로 사료된다.

\section{ORCID}

Woo Yong Bae https://orcid.org/0000-0001-5578-0225

\section{REFERENCES}

1) Kellerhals B. de Uthemann B. Woakes' syndrome: the problems of infantile nasal polyps. Int J Pediatr Otorhinolaryngol 1979;1(1):79-85.

2) Schoenenberger U, Tasman AJ. Adult-onset woakes' syndrome: 
report of a rare case. Case Rep Otolaryngol 2015;2015:857675.

3) Abbud-Neme F, Reynoso VM, Deutsch Reiss E. Woake's syndrome. a case report in a teenager. Int J Pediatr Otorhinolaryngol 1987;12 (3):327-33.

4) Misato U, Kazunobu H, Takanori I, Hiroto T. Rhinoplasty via the midface degloving approach for nasal deformity due to nasal polyps: a case report of Woakes' syndrome. Oral and Maxillofacial Surgery Cases 2017;3(3):64-9.

5) Groman JD, Bolger W, Brass-Ernst L, Macek M Jr, Zeitlin P, Cutting G. Recurrent and destructive nasal polyposis in 2 siblings: a possible case of Woakes' syndrome. Otolaryngol Head Neck Surg 2004;131
(6):1009-11.

6) Molga P, Fendler W, Borowiec M, Pietruszewska W. Impact of -1607 1G/2G MMP1 gene polymorphism on the morbidity and clinical course of chronic rhinosinusitis with nasal polyps. Otolaryngol Pol 2016;70(1):24-33.

7) Caversaccio M, Baumann A, Helbling A. Woakes' syndorme and albinism. Auris Nasus Larynx 2007;34(2):245-8.

8) Stevens WW, Peters AT, Immunodeficiency in chronic sinusitis: recognition and treatment. Am J Rhinol Allergy 2015;29(2):115-8.

9) Chiarella SE, Grammer LC. Immune deficiency in chronic rhinosinusitis: screening and treatment. Expert Rev Clin Immunol 2017;13(2):117-23. 